\title{
Microwave Assisted Chloride Leaching of Zinc Plant Residues
}

\author{
Thomas Abo Atia ${ }^{1,2}$, Jeroen Spooren ${ }^{1}$ \\ ${ }^{1}$ VITO, Waste Recycling Technologies, Flemish Institute for Technological Research \\ VITO N.V., Boeretang 200, 2400 Mol, Belgium \\ ${ }^{2}$ SIM vzw, Technologiepark 48, 9052 Zwijnaarde, Belgium \\ thomas.aboatia@vito.be; jeroen.spooren@vito.be
}

\section{Extended Abstract}

The present work focusses on the valorisation of two zinc plant residues coming from hydrometallurgical zinc production [1]: goethite sludge and Zn-leaching residue. The goethite sludge is a hazardous waste material, due to the presence of heavy metals ( $\mathrm{As}, \mathrm{Cd}, \mathrm{Cu}, \mathrm{Pb}$ and $\mathrm{Zn}$ ) and is currently dumped on site or ponded, while the leach product is further processed by smelter industry for lead and silver recovery. Both materials contain low concentrations of critical raw material, defined by the European Commission [2], as well as valuable metals, such as $\mathrm{Pb}(1.8 \mathrm{wt} \%)$ and $\mathrm{Zn}(5.9 \mathrm{wt} \%)$ in goethite sludge and $\mathrm{Pb}(14-15 \%), \mathrm{Zn}(3.6 \%), \mathrm{Sb}(\approx 0.2 \%)$ and $\mathrm{Bi}(\approx 0.1 \%)$ in leach product.

These low amounts of valuable materials in the wastes and the complexity of downstream separations make the recovery processes economically unviable. To reduce the economic impact of traditional metallurgy, advanced microwave hydrometallurgy and its intrinsic benefits (including fast and selective heating, enhanced kinetics promoted by hydrothermal conditions, reduced energy consumption, control and reproducibility [3]) can play a key role to enable secondary resources recovery and decontamination of the mineral matrix of these zinc plant residues.

For this purpose, microwave (MW) assisted $\mathrm{NaCl}$ leaching was investigated as a method to selectively extract $\mathrm{Pb}$ and $\mathrm{Zn}$ from goethite sludge through the formation of soluble chloride complexes. Roughly, $85 \%$ of $\mathrm{Pb}$ and $50 \%$ of $\mathrm{Zn}$ were $\mathrm{MW}$ leached at $200{ }^{\circ} \mathrm{C}$ for 30 minutes in a closed reactor vessel using $300 \mathrm{~g} / \mathrm{l} \mathrm{NaCl}$ solution. Also, Cu recovery was about $40 \%$. Minor dissolution of the matrix elements ( $\mathrm{Fe}<30 \mathrm{ppb}$ and $\mathrm{Ca} \approx 15 \%$ ) took place. Furthermore, a kinetic study evidenced similar extractive performances when the leaching time was reduced to $10 \mathrm{~min}$.

The same leaching concept (MW leaching, $280 \mathrm{~g} / 1 \mathrm{NaCl}, 200{ }^{\circ} \mathrm{C}, 30 \mathrm{~min}$ ) was transferred to the Zn-leach product. The optimization of this process is currently ongoing and preliminary results showed that $\mathrm{Pb}, \mathrm{Zn}$ and $\mathrm{Bi}$ leached at least $50 \%$, $20 \%$ and 50\%, respectively (Sb only 1\%). This treatment resulted selective with respect to the matrix components (e.g. silicate and gypsum/anhydrite minerals: $\mathrm{Si}$ and $\mathrm{Ca}$ only dissolved for 0.3 and $\approx 13 \%$, respectively). To increase the solubility of antimony, hydrochloric acid was added to the lixiviant [4]. Explorative MW leaching experiments $\left(200{ }^{\circ} \mathrm{C}, 30 \mathrm{~min}\right)$ employing $0.1 \mathrm{M} \mathrm{HCl}+280 \mathrm{~g} / \mathrm{L} \mathrm{NaCl}$ and $1 \mathrm{M} \mathrm{HCl}+220 \mathrm{~g} / \mathrm{l} \mathrm{NaCl}$ indicated that $\mathrm{Zn}, \mathrm{Bi}$ and $\mathrm{Sb}$ extractions increased (approximately to $70 \%, 85 \%$ and $40 \%$, respectively). On the other hand, matrix solubilization increased and Pb extraction decreased upon increasing acidity.

In conclusion, a selective leaching of $\mathrm{Pb}$ and $\mathrm{Zn}$ from the goethite sludge can be achieved by microwave assisted $\mathrm{NaCl}$ leaching $(300 \mathrm{~g} / \mathrm{L})$ at $200{ }^{\circ} \mathrm{C}$. Whereas, promising leaching selectivity for $\mathrm{Zn}, \mathrm{Pb}$ and $\mathrm{Bi}$ was observed for MW chloride leaching $(280 \mathrm{~g} / \mathrm{L} \mathrm{NaCl})$ of $\mathrm{Zn}$-leach product. Addition of $\mathrm{HCl}$ to the leaching solution, enhanced the leachability of $\mathrm{Sb}$, Bi and $\mathrm{Zn}$, but reduced selectivity.

\section{References}

[1] F. Habashi, Textbook of Hydrometallurgy. Metallurgie Extractive Quebec, $2^{\text {nd }}$ edition, pp. 268-273.

[2] European Commission, Study on the review of the list of Critical Raw Materials. Directorate-General for Internal Market, Industry, Entrepreneurship and SMEs Directorate Industrial Transformation and Advanced Value Chains Unit, European Commission, European Union, 2017

[3] D.A. Jones, "Microwave heating applications in environmental engineering — a review," Resour. Cons. Recy., vol. 34, no. 2, pp. 75-90, 2002

[4] R. Zhang, "Ultrasound-assisted $\mathrm{HCl}-\mathrm{NaCl}$ leaching of lead-rich and antimony-rich oxidizing sludge," Ultrason Sonochem., vol. 27, pp. 187-191, 2015 